\title{
Pengaruh LKS Laboratorium Virtual Fisika Dalam Pendekatan Saintifik Materi Fluida Terhadap Hasil Belajar Siswa Kelas XI SMAN 14 Padang
}

\author{
Muhammad Tri Bimo $^{1)}$, Asrizal ${ }^{2}$, Hidayati $^{2)}$ \\ ${ }^{1)}$ Lulusan Program Studi Pendidikan Fisika FMIPA Universitas Negeri Padang \\ ${ }^{2)}$ Dosen Fisika FMIPA Universitas Negeri Padang \\ mtribimo@gmail.com, asrizal_unp@yahoo.com, hidayati_unp@yahoo.com
}

\begin{abstract}
Experiment is important to support good learning outcomes of students. However, the application of the experiment can't be done well in school. The solution of this problem is to apply the virtual laboratory student worksheet in scientific approach. Application of laboratory virtual student worksheet in scientific approach is expected to support students to learn actively so that it can improve the learning outcomes of students. The objective of the research was to investigate the influence of virtual laboratory student worksheet with in scientific approach toward study outcomes of students. In this quasi experimental was used randomized control group only design. The population of this research consist of all of students SMA N 14 Padang grade XI with the total number of 163 students. The sample of the research were taken by purposive sampling technique. Instruments for collecting the data consist of written test for knowledge aspect, observation sheet for attitude aspect and performance assessment sheet for skills aspect. Research data were analyzed by descriptive statistic, normality test and homogeneity test and mean comparison test. Based on the data analysis can be stated that the use of virtual laboratory student worksheet in scientific approach has given a significant effect on physics learning outcomes of students on knowledge aspect, attitudes aspect and skills aspect on grade XI students in SMA N 14 Padang at the siginificant confidence $95 \%$.
\end{abstract}

Keywords : Student worksheet, Virtual laboratory, Fluids, and Scientific approach

(A) his is an open access article distributed under the Creative Commons 4.0 Attribution License, which permits unrestricted use, distribution, and reproduction in any medium, provided the original work is properly cited . $\$ 2018$ by author and Universitas Negeri Padang.

PENDAHULUAN

Pendidikan di sekolah merupakan sebuah kepentingan yang wajib diterima oleh semua lapisan masyarakat. Pembangunan sebuah negara sangat dipe ngaruhi oleh sebuah sistem pendidikannya. Pendidik an yang berkualitas merupakan sebuah upaya untuk membangunkan generasi penerus untuk bersaing dengan perkembangan dunia yang sangat maju. Tujuan pendidikan nasional merupakan salah satu usaha dari Badan Standar Nasional Pendidikan pada tahun 2010 untuk menggagaskan pendidikan di Indonesia.

Pendidikan abad 21 memiliki tujuan yaitu untuk merealisasikan harapan dari negara Indonesia. Pendidikan dituntut dapat menciptakan masyarakat yang memiliki keinginan yang kuat untuk belajar. Indonesia diharapkan memiliki posisi setara dengan negara-negara lain didunia dan dihormati olah semua negara didunia, dengan terciptanya masyarakat yang berkualitas melalui pendidikan terdapat individu atau pribadi yang memiliki sifat untuk merealisasikan harapan negara Indonesia ${ }^{[1]}$.

Kurikulum 2013 menekankan pada proses pembelajaran aktif. Proses pembelajaran tersebut siswa dituntut untuk aktif bertanya mengenai materi yang dipelajari, mengamati hal-hal yang bersangkut paut terhadap materi, menanya hal yang berkaitan dengan materi, mengumpulkan informasi tentang materi, mengasosiasikan dan mengkomunikasikan tentang materi yang telah dipelajari ${ }^{[2]}$. Hal ini dapat terealisasi apabila pendidik dapat mengaplikasikan pembelajaran inovatif dan kreatif melibatkan siswa secara aktif dalam setiap proses pembelajaran yang membentuk dan meningkatkan pengembangan sikap sosial, dan keterampilan umum.

Pembelajaran fisika pada kurikulum 2013 merupakan proses untuk mendapatkan informasi. Mencari informasi dapat dengan menggunakan metode empiris, informasi yang didapatkan ketika penyelidikan yang sudah ditata sistematis, dan suatu gabungan pola pikir kritis membuahkan hasil infor masi valid dan dapat dipercaya ${ }^{[3]}$. Berdasarkan pengertian ini, pembelajaran fisika merupakan ilmu sains yang berhubungan dengan proses menyelidiki informasi sampai menghasilkan informasi yang akurat atau valid.

Fisika adalah pelajaran yang diajarkan di sekolah yang menjadi dasar perihal berkembangnya ilmu pengetahuan dan teknologi yang dapat mewujud kan tujuan pendidikan nasional. Tujuan pembelajaran fisika adalah untuk menguasai konsep, prinsip dan mempunyai keterampilan untuk meningkatkan ilmu pengetahuan dan sikap ingin tahuyang berguna untuk bekal meneruskan pendidikan ke jenjang berikutnya serta meningkatkan kualitas ilmu pengetahuan dan teknologi. Fisika memiliki peranan sangat penting karena mempelajari berbagai hal tentang pengetahu an sehingga dapat mengembangkan daya nalar dan analisis siswa. Untuk menyelesaikan permasalahan pada fisika dapat dimulai dengan penguasaan konsep 
dasar, agar peserta didik dapat memahami konsep yang lebih luas.

Eksperimen merupakan kegiatan yang penting dalam pembelajaran fisika. Alasannya adalah Fisika adalah ilmu pengetahuan eksperimental dan ilmu pengetahuan yang didasarkan pada observasi eksperi mental $^{[4]}$. Kegiatan eksperimen dalam pelajaran sains sangat berguna terutama dalam bidang studi fisika, namun selama ini tidak dijabarkan bagaimana cara agar kegiatan eksperimen tersebut dapat membentuk siswa yang aktif dan kreatif ${ }^{[5]}$. Eksperimen laborato rium virtual merupakan salah satu upaya untuk melaksanakan eksperimen jika terdapat banyak keterbatasan dalam melakukan eksperimen. Dalam kegiatan eksperimen pendidik dapat memberikan peserta didik berupa media yang membantu siswa dalam melakukan eksperimen seperti bahan ajar dalam bentuk LKS.

LKS merupakan materi ajar yang sudah dikemas sedemikian rupa sehingga siswa diharapkan mampu untuk mempelajari materi ajar tersebut secara mandiri ${ }^{[6]}$. Pengertian lain dari LKS adalah kumpulan dari beberapa lembaran yang sudah terisikan dengan kegiatan dan aktivitas nyata untuk siswa menyelesaikan suatu permasalahan yang dipelajari secara nyata. Pengertian lain dari LKS dapat berfungsi untuk membimbing siswa dalam suatu pembelajaran dan mempermudah kegiatan siswa dan guru dalam proses pembelajaran ${ }^{[7]}$. LKS yang baik adalah LKS yang membuat peserta didik untuk aktif dalam melakukan kegiatan, baik kegiatan eksperimen mau pun diskusi. LKS merupakan salah satu perangkat yang utama untuk menunjang aktivitas peserta didik. Oleh karena itu, pendidik harus bisa membuat LKS yang akan diberikan ke peserta didik semenarik mungkin ${ }^{[8]}$.

Kondisi yang ditemukan di lapangan belum sesuai dengan yang diharapkan. Kenyataan pertama yang ditemukan guru mata pelajaran fisika belum menerapkan semua kriteria pendekatan saintifik dalam kegiatan pembelajaran, guru masih dominan memakai metode lama yaitu ceramah dan siswa hanya mendengarkan tanpa adanya umpan balik dalam proses pembelajaran. Kenyataan kedua alatalat yang terdapat di laboratorium masih belum lengkap untuk digunakan. Hanya untuk beberapa materi saja yang bisa dilaksanakan eksperimen, sedangkan materi lain yang wajib dilakukan eksperimen tidak dilaksanakan karena keterbatasan alat laboratorium. Peneliti menilai dalam proses pembelajaran dapat digunakan media yang berfungsi lebih baik, efektif dan efisien yaitu menggunakan laboratorium virtual dalam proses pembelajaran. Kenyataan ketiga didapat dari hasil belajar fisika siswa. Data yang diperoleh didapatkan dari TU SMA 14 Padang yaitu rata-rata nilai fisika siswa adalah 63.82 hanya berada pada kategori cukup. Dari data yang telah diperoleh tersebut juga dapat diketahui adanya beberapa masalah yang dialami oleh siswa ketika kegiatan pembelajaran sedang berlangsung.

Dari permasalahan dalam proses pembelajaran yang telah dijabarkan dapat diambil subuah solusi yaitu dengan menggunakan LKS laboratorium virtual. Eksperimen laboratorium virtual dapat digunakan hanya dengan menggunakan aplikasi yang telah terinstal pada laptop tanpa harus menggunakan alat-alat pada laboratorium. Eksperimen ini membuat siswa lebih tertarik untuk melakukan eksperimen sehingga para siswa tersebut dapat menjalan eksperi men dengan baik ${ }^{[9]}$. Hasil eksperimen yang baik juga dapat menunjang pemahaman siswa tentang materi dan hasil belajar yang meningkat.

Pembelajaran fisika dengan menggunakan pendekatan saintifik merupakan faktor yang dapat menunjang keberhasilan dalam pembelajaran. Ketika proses pembelajaran berlangsung siswa cenderung tidak jenuh atau bosan untuk mengikuti kegiatan eksperimen menggunakan laboratorium virtual juga dapat meningkatkan motivasi belajar siswa terhadap fisika. Kegiatan eksperimen menggunakan laboratori um virtual dapat menciptakan siswa yang kreatif dan meningkatkan perasaan ingin tahu dari siswa tersebut terhadap permasalahan fisika ${ }^{[10]}$.

Laboratorium virtual dapat diartikan sebagai sebuah kegiatan yang interaktif untuk melakukan dan menciptakan sebuah eksperimen tanpa menggunakan alat laboratorium. Domain dependent program dan unit eksperimental objek merupakan komponen yang terdapat pada laboratorium virtual. Pada unit ekperi mental terdapat objek berisi file data, buku referensi dan alat bekerja pada benda sekitar. Laboratorium virtual dapat dijadikan alternatif dalam melakukan eksperimen jika keterbatasan alat pada laboratorium.

Simulasi dan animasi merupakan dua kompo nen yang penting didalam laboratorium virtual. Simulasi mempunyai tujuan untuk menggambarkan lingkungan nyata ke dalam bentuk sistem. Simulasi memungkinkan peserta didik untuk dapat melakukan eksperimen dengan cara mengganti parameter-para meter yang tedapat didalamnya. Hal ini membuat munculnya perilaku-perilaku yang berbeda terhadap kegiatan eksperimen yang dilakukan. Hal yang berbeda ini lalu ditampilkan melalui sebuah animasi. Hasil eksperimen akan langsung terekam oleh sistem secara otomatis.

Laboratorium virtual memiliki banyak sekali keuntungan dalam pembelajaran. Keuntungan yang pertama yaitu mengurangi waktu eksperimen jika dilakukan secara langsung. Keuntungan yang kedua dapat mengadakan eksperimen tanpa perlu merasa khawatir apabila melakukan kegiatan praktikum yang cukup berbahaya. Keuntungan yang ketiga lebih menghemat biaya melalui praktikum yang sama. Keuntungan Laboratorium virtual yang lain yaitu menyediakan akses untuk menggunakan peralatan eksperimen yang mahal, mengurangi dana bepergian 
ke laboratorium, dan memungkinkan semua peserta didik dapat berkolaborasi secara aktif.

Laboratorium virtual dapat dijadikan solusi untuk melakukan kegiatan eksperimen kapan pun dan dimana pun siswa berada. Hanya dengan bermodal kan software virtual siswa dapat mengakses kegiatan eksperimen. Laboratorium virtual memiliki fungsi dan tujuan untuk memberikan pengetahuan baik konseptual dan prosedural ${ }^{[11]}$.

Penelitian yang dilakukan haruslah terarah untuk mendapatkan tujuan yang harus dicapai. Tujuan yang diraih dari penyelidikan yang dikerjakan adalah menyelidiki pengaruh LKS laboratorium virtual dalam pendekatan saintifik materi fluida terhadap pencapaian nilai siswa pada kelas XI SMAN 14 Padang.

\section{METODE PENELITIAN}

Jenis penyelidikan yang dikerjakan ini ialah quasi eksperimen. Penelitian quasi memberikan keuntungan penyelenggaraan reaktif dapat dikurangi pada kelas yang sama-sama digunakan dalam proses penelitian. Penelitian ini menggunakan desain hanya kelas kontrol terandomisasi yang membutuhkan dua kelas sebagai objek dalam penelitian. Kelas eksperi men pada proses pembelajarannya memakai LKS laboratorium virtual dalam pendekatan saintifik dan kelas kontrol tidak memakai LKS laboratorium virtual. Sebelum kegiatan penelitian berakhir, kedua kelas sampel diberikan tes akhir untuk menilai hasil belajar yang didapatkan siswa.

Populasi merupakan keseluruhan dari anggota dalam suatu lingkungan dari subjek penelitian. Popu lasi memiliki karakteristik dan kuantitas masingmasing yang ditentukan oleh peneliti. Semua siswa kelas XI yang tercantum pada semester 1 SMAN 14 Padang merupakan populasi dari penelitian ini.

Sampel pada penyelidikan ini dua kelas, yakni eksperimen dan kontrol. Pengambilan kelas sampel menggunakan kombinasi dari purposive sampling yang dilakukan berdasarkan tujuan tertentu. Pengam bilan sampel pada penyelidikan ini berdasarkan kepada satu guru mengajar di kedua kelas dan juga jam pembelajaran pada fisikanya sama dalam satu minggu. Data yang diterima dalam percobaan, yaitu data hasil belajar siswa pada tiap aspek kompetensi yaitu pengetahuan, sikap, dan keterampilan. Tes akhir dilakukan kepada siswa untuk mengambil penilaian hasil belajar, penilaian aspek sikap siswa diambil dengan menggunakan instrument penilaian sikap dan penilaian aspek keterampilan siswa digunakan instrumen penilaian tugas kinerja eksperi men dari siswa.

Penelitian yang dilakukan secara umum dapat dikelompokkan atas tiga tahap. Tahapan penelitian mencakup tahapan persiapan, tahapan pelaksanaan, dan tahapan penyelesaian. Tahapan persiapan, menyiapkan semua bahan untuk proses penyelidikan seperti RPP, eksperimen virtual lab dan LKS laboratorium virtual. Pada tahap persiapan peneliti membuat gambaran soal ujian untuk kedua kelas, mengerjakan uji coba soal dengan menentukan reabilitas soal untuk menentukan berapa jumlah soal yang akan digunakan untuk postes.

Kedua adalah tahapan pelaksanaan, proses pada pembelajaran pada kelas sampel menggunakan kurikulum 2013. Pendekatan yang digunakan untuk kedua kelas sampel yaitu pendakatan saintifik, sedangkan perlakuan terhadap kedua kelas sampel ini berbeda. Pada kelas eksperimen diberikan perlakuan yaitu memakai LKS laboratorium virtual, sementara pada kelas kontrol tidak diberikan perlakuan tanpa memakai LKS laboratorium virtual. Kelas eksperi men melakukan eksperimen dengan menggunakan laboratorium virtual sedangkan kelas kontrol melaku kan eksperimen di laboratorium.

Pada tahap penyelesaian, peneliti mengumpul kan semua data dari kompetensi siswa pada aspek pengetahuan dengan mengadakan tes akhir pada kedua kelas melalui soal postes. Mengumpulkan data nilai aspek sikap siswa menggunakan instrument penilaian sikap dilakukan pada setiap proses pembelajaran. Mengumpulkan nilai hasil belajar pada aspek keterampilan siswa dengan menggunakan skala penilaian juga dilakukan pada setiap kegiatan eksperimen. Disamping itu, analisis data dilakukan pada data kompetensi siswa pada aspek pengetahuan, sikap, dan keterampilan melalui uji statistik.

Instrumen merupakan alat yang digunakan untuk merekam data yang memiliki tahapan terstruktur. Instrumen yang dipakai dalam penyelidik an ini pada aspek pengetahuan adalah tes tertulis yang berbentuk objektif dan mengacu pada indikator hasil belajar berupa pengetahuan, sedangkan pada aspek sikap menggunakan lembar observasi yang dikembangkan sesuai dengan penilaian aspek yang dibutuhkan pada pembelajaran berlangsung, lalu pada aspek keterampilan digunakan skala penilaian unjuk kerja.

Teknik analisis pada penelitian memiliki tujuan untuk menguji kebenaran dugaan sementara yang dikemukakan pada penelitian ini. Teknik analisis statistik merupakan kumpulan data yang bergun untuk memberikan deksripsi menyinggung suatu kondisi biasanya berupa angka yang disusun dalam bentuk tabel atau diagram. Teknik persentase merupakan teknik penilaian yang dapat dipakai untuk menghitung kemajuan hasil belajar. Teknik persentase termasuk aspek sikap, aspek keterampilan dan pengetahuan. Nilai untuk semua aspek bisa dihitung dengan menggunakan cara nilai yang diper oleh dibagi dengan nilai maksimum.

$$
\text { Nilai }=\frac{\text { Skoryangdiperole } h}{\text { Skormaksimum }} \times 100
$$

Teknik analisis data untuk aspek pengetahuan dengan menggunakan uji kesamaan rata-rata. Sebe lumnya dilakukan uji normalitas yang mampu menganalisis apakah populasi tersebut memiliki distribusi normal atau tidak normal. Cara mengetahui 
normalitas suatu populasi dilakukan uji yang bernama lilliefors dengan langkah-langkah yaitu mencari simpangan baku data, mencari perbandigan skor $\mathrm{L}_{0}$ dengan $\operatorname{skor} L_{t}$ untuk taraf signifikan $0,05^{[13]}$.

Uji kesamaan rata-rata merupakan bagian dari uji hipotesis. Uji ini berguna untuk uji statistik yang digunakan untuk melihat kesamaan dari rata-rata. Kompetensi yang diuji pada hal ini meliputi aspek pengetahuan, sikap, dan keterampilan dengan melakukan uji homogenitas untuk melihat kedua sampel memiliki varians yang homogen atau tidak. Setelah itu langsung menggunakan uji kesamaan rata-rata. Uji ini berguna untuk melihat apakah adanya perbedaan yang berarti antara nilai kedua kelas sampel pada penelitian ini. Data hasil belajar fisika pada aspek pengetahuan, sikap, serta keteram pilan terditribusi normal dan homogen maka uji kesamaan dua rata-rata yang dipakai adalah uji $t$.

$t=\frac{\overline{X_{1}}-\overline{X_{2}}}{S \sqrt{\frac{1}{n_{1}}+\frac{1}{n_{2}}}} \mathrm{dan} S^{2}=\frac{\left(n_{1}-1\right) S_{1}^{2}+\left(n_{2}-1\right) S_{2}^{2}}{n_{1}+n_{2}-2}$

Kriteria pengujian yang diperlukan harga $t_{h}$ dibandingkan dengan $t_{t}$. Apabila nilai $t_{h}$ berada diantara nilai $t_{t}$ maka hipotesis Ho diterima. Sebaliknya apabila nilai $t_{h}$ berada diluar daerah $t_{t}$ maka hipotesis Ho ditolak. Adanya perbedaan nilai $t_{h}$ dengan nilai $t_{t}$ yang berarti akan dijadikan acuan untuk menyatakan hipotesis diterima atau tidak. Hipotesis Ho akan diterima apabila nilai $t_{h}$ berada di luar daerah penerimaan Ho.

\section{HASIL PENELITIAN DAN PEMBAHASAN}

\section{Hasil Penelitian}

Penyelidikan ini dilakukan di SMA Negeri 14 Padang. Sampel pada penyelidikan ini ialah kelas yang terdapat pada SMA N 14 padang yakni MIA 1 dan MIA 2. Kedua kelas ini merupakan kelas sampel. Data yang diperoleh dalam penelitian ini penilaian dari semua aspek yang meliputi pengetahuan, sikap, dan keterampilan siswa. Data dari penilaian pada aspek pengetahuan didapatkan dari tes tertulis yang diadakan pada akhir kegiatan penelitian. Data penilaian aspek sikap didapatkan selama proses pembelajaran berlangsung dengan mengisi format penilaian sikap. Data penilaian aspek keterampilan didapatkan selama kegiatan eksperimen berlangsung dengan mengisi format penilaian keterampilan. Secara garis besar terdapat dua hasil yang didapatkan selama penyelidikan yaitu perbedaan nilai belajar siswa dan pengaruh penerapan LKS laboratorium virtual dalam pendekatan saintifik.

Penilaian hasil belajar siswa pada penilaian aspek pengetahuan didapatkan dari tes akhir. Soal pada tes akhir untuk kedua kelas ini berupa pilihan ganda yang berjumlah 35 butir. Soal ini berguna untuk melihat pengaruh LKS laboratorium virtual terhadap nilai belajar siswa pada kompentensi aspek pengetahuan. Hasil perhitungan diperoleh berupa nilai rata-rata, varians kelas sampel, dan simpangan yang digambarkan pada Tabel 1.

Tabel 1. Penilaian Kelas pada Aspek Pengetahuan

\begin{tabular}{lrrrc}
\hline \multicolumn{1}{c}{ Kelas } & $\mathrm{N}$ & $\mathrm{Xr}$ & $\mathrm{S}$ & $\mathrm{S}^{2}$ \\
\hline Eksperimen & 32 & 81,12 & 6,68 & 47,19 \\
Kontrol & 32 & 75,12 & 6,07 & 36,74 \\
\hline
\end{tabular}

Dari data pada Tabel 1 dapat dijelaskan tiga hal. Pertama, nilai rata-rata pada aspek pengetahuan siswa pada kelas sampel menunjukan perbedaan yaitu lebih tinggi nya nilai yang diperoleh untuk kelas XI MIA 1 dibandingkan dengan nilai pada XI MIA 2. Siswa memperoleh nilai rata-rata sebesar 81,1 pada kelas eksperimen dan 75,1 untuk kelas control. Kedua, nilai untuk kelas eksperimen kian merata dibandikan dengan nilai untuk kelas kontrol dikarenakan skor simpangan yang didapat untuk kelas MIA 1 lebih kecil dibandingkan MIA 2.

Ketiga, nilai yang didapat untuk kelas MIA 2 lebih beragam dibandingkan MIA 1 dibuktikan dengan varians kelas eksperimen lebih rendah dari kontrol. Rincian ketuntasan minimal siswa untuk kelas eksperimen dari 32 siswa adalah sebanyak 16 siswa sedangkan pada kelas kontrol dari 32 siswa hanya sebanyak 6 siswa. Hal ini menunjukkan perbedaan penilaian belajar fisika antara siswa yang diberi LKS laboratorium virtual dalam pendekatan saintifik dengan siswa yang tidak beri LKS laborato rium virtual dalam pendekatan saintifik.

Untuk melihat perbedaan penilaian aspek pengetahuan kedua kelas signifikan atau tidak, digunakan uji kesamaan rata-rata. Sebelum dilakukan uji perbedaan ini terlebih dahalu dilakukan uji normalitas dan homogenitas. Uji normalitas berfung si mengecek apakah kedua kelas memiliki distribusi normal atau tidak. Nilai $L o$ dan $L t$ untuk taraf signifikan 0,05. Hasil dari uji normalitas telah dipaparkan ke Tabel 2.

Tabel 2. Nilai Uji Normalitas Aspek Pengetahuan

\begin{tabular}{lcrrrl}
\hline \multicolumn{1}{c}{ Kelas } & $\alpha$ & $\mathrm{N}$ & Lo & Lt & Keterangan \\
\hline Eksperimen & \multirow{2}{*}{0,05} & 32 & 0,094 & 0,157 & Normal \\
Kontrol & & 32 & 0,112 & 0,157 & Normal \\
\hline
\end{tabular}

Dari Tabel 2 dapat digambarkan bahwa nilai $\mathrm{L}_{\mathrm{o}}$ untuk kelas eksperimen ialah 0,094 dan nilai $\mathrm{L}_{\mathrm{o}}$ untuk kelas kontrol ialah 0,112. Data yang didapatkan ternyata nilai $\mathrm{L}_{\mathrm{o}}<\mathrm{L}_{\mathrm{t}}$. Pada taraf signifikan 0,05 nilai $\mathrm{L}_{\mathrm{t}}$ untuk $\mathrm{n}=32$ adalah 0,157 sehingga dapat dinyatakan bahwa kedua kelas sampel sama-sama terdistribusi secara normal.

Untuk melihat apakah data dari kedua kelas sampel yaitu eksperimen dan kontrol mempunyai varians yang seragam atau tidak seragam dilakukan uji homogenitas. Dari hasil perhitungan yang telah didapatkan dapat ditampilkan pada Tabel 3. 
Tabel 3. Nilai Uji Homogenitas AspekPengetahuan

\begin{tabular}{lccccc}
\hline \multicolumn{1}{c}{ Kelas } & $\mathrm{N}$ & $\mathrm{S}^{2}$ & $\mathrm{~F}_{\mathrm{h}}$ & $\mathrm{F}_{\mathrm{t}}$ & Keterangan \\
\hline Eksperimen & 32 & 47,196 & 1,28 & 1,83 & Homogen \\
Kontrol & 32 & 36,845 & & & \\
\hline
\end{tabular}

Dari Tabel 3 untuk menentukan $\mathrm{F}_{\mathrm{h}}$ dilakukan pemba gian variansi terbesar dibagi dengan variansi terkecil. Hasil uji homogenitas untuk kedua kelas didapatkan nilai $\mathrm{F}_{\mathrm{h}}=1,28$ dan $\mathrm{F}_{\text {tabel }}$ adalah 1,83 pada taraf nyata 0,05 dapat disimpulkan jika nilai $\mathrm{F}_{\mathrm{h}}<\mathrm{F}_{\mathrm{t}}$ maka sampel dinyatakan mempunyai varians homogen.

Kedua kelas dinyatakan memiliki distribusi yang normal dan memiliki varian yang seragam, karena telah dilaksnakandua uji sebelumnya yakni normalitas dan homogenitas. Selanjutnya dilakukan uji kesamaan rata-rata untuk menguji hipotesis dari peneletian ini. Statistik uji-t dipakai dalam uji kesamaan rata-rata. Hasil perhitungan uji kesamaan rata-rata telah diperlihatkan pada Tabel 4.

Tabel 4. Nilai Uji t Aspek Pengetahuan

\begin{tabular}{lccccc}
\hline \multicolumn{1}{c}{ Kelas } & $\mathrm{N}$ & $\mathrm{X}$ & $\mathrm{S}^{2}$ & $\mathrm{t}_{\mathrm{h}}$ & $\mathrm{t}_{\mathrm{t}}$ \\
\hline Eksperimen & 32 & 81,1 & 47,196 & 3,7 & 2,0 \\
Kontrol & 32 & 75,1 & 36,845 & & \\
\hline
\end{tabular}

Pada Tabel 4 dapat dinyatakan nilai $t_{h}$ dari kedua kelas sampel. Nilai yang didapatkan setelah dilaku kan analisis statistik sebesar $t_{h}=3,7$ Nilai $t_{t}$ untuk dk $=\mathrm{n}-2$ sebesar $\mathrm{t}_{\mathrm{t}}=2,00$. Syarat pengujian $\mathrm{H}_{0}$ diterima jika nilai th berada diantara tt. Hi dikatakan diterima pada taraf nyata 0,05 jika harga $t_{h}$ di luar daerah penerimaan Ho.

Kondisi awal kedua kelas pada aspek penge tahuan siswa tidak memiliki perbedaan yang signifi kan dapat dikatakan hampir sama. Pada kedua kelas telah dilakukan tes sebelum menentukan kelas sampel. Setelah penggunaan LKS laboratorium vir tual ternyata terdapat perbedaan yang berarti. Ada nya perbedaan yang berarti pada aspek pengetahuan mengindikasikan adanya pengaruh penggunaan dari LKS laboratorium virtual. Dengan demikian, penggu naan LKS laboratorium virtual memberikan pengaruh terhadap aspek pengetahuan siswa.

Pengaruh LKS laboratorium virtual pada aspek sikap dinilai secara langsung. Penilaian sikap siswa dilakukan ketika proses pembelajaran didalam kelas. Data diambil menggunakan instrumen penilai an sikap yang dalam pelaksanaannya dibantu seorang observer. Penilaian aspek sikap terbagi atas enam aspek penilaian. Deskripsi dari data penilaian aspek sikap siswa ini ditunjukkan dari nilai total siswa selama proses penelitian yaitu sebanyak enam kali di dalamruang kelas. Deskripsi penilaian aspek sikap siswa ditampilkan pada Tabel 5.

Tabel 5. Penilaian Kelas Sampel AspekSikap

\begin{tabular}{lcccc}
\hline \multicolumn{1}{c}{ Kelas } & $\mathrm{N}$ & $\mathrm{Xr}$ & $\mathrm{S}$ & $\mathrm{S}^{2}$ \\
\hline Eksperimen & 32 & 87 & 2,63 & 6,91 \\
Kontrol & 32 & 83 & 3,32 & 11,00 \\
\hline
\end{tabular}

Dari Tabel 5. dapat dijelaskan tiga hal. Pertama, nilai rata-rata pada aspek sikap siswa pada kelas sampel menunjukan perbedaan yaitu lebih tingginya nilai untuk kelas eksperimen dibandingkan kelas kontrol. Kedua, skor kelas MIA 1 lebih merata dibanding skor MIA 2 karena nilai simpangan kelas MIA 1 lebih kecil dari pada MIA 2. Ketiga, skor untuk varians pada kelas MIA 1 lebih rendah dibanding skor MIA 2. Berarti aspek sikap siswa yang terdapat pada kelas kontrol lebih beragam.

Guna dari uji homogenitas ialah untuk menilai skor dari kedua kelas sampel memiliki varians yang seragam atau tidak seragam. Hasil perhitungan uji homogenitas dinyatakan kedalam bentuk Tabel 6 .

Tabel 6. Nilai Uji HomogenitasAspek Sikap

\begin{tabular}{lccccc}
\hline \multicolumn{1}{c}{ Kelas } & $\mathrm{N}$ & \multicolumn{1}{c}{$\mathrm{S}^{2}$} & $\mathrm{Fh}$ & $\mathrm{Ft}$ & Keterangan \\
\hline Eksperimen & 32 & 2,91 & 1,59 & 1,83 & Homogen \\
Kontrol & 32 & 11,02 & & & \\
\hline
\end{tabular}

Tabel 6 menjelaskan hasil perhitungan dari uji homogenitas untuk kedua kelas sampel pada aspek sikap. Hasil Fh didapatkan untuk kedua kelas sampel yaitu 1.59. Nilai $F_{h}<F_{t}$ menyatakan kedua kelas sampel mempunyai varians yang seragam.

Uji hipotesis dilaksanakan setelah didapatkan hasil kedua uji sebelumnya. Uji hipotesis berguna mengetahui hipotesis kerja diterima atau ditolak. Uji hipotesis yang dilaksanakan memakai uji kesamaan rerata. Data yang didapat memiliki distribusi normal dan memiliki varians yang seragam, sehingga digunakan uji $t$ guna mencari hasil hipotesis. Nilai uji t digambarkan di Tabel 7.

Tabel 7. Hasil Uji t Aspek Sikap

\begin{tabular}{lccccc}
\hline \multicolumn{1}{c}{ Kelas } & $\mathrm{N}$ & $\mathrm{X}$ & \multicolumn{1}{c}{$\mathrm{S}^{2}$} & $\mathrm{t}_{\mathrm{h}}$ & $\mathrm{t}_{\mathrm{t}}$ \\
\hline Eksperimen & 32 & 87,0 & 6,91 & & \\
Kontrol & 32 & 83,0 & 11,02 & 5,7 & 2,0 \\
\hline
\end{tabular}

Dari analisis data pada Tabel 7 dapat dinyatakan bahwa nilai rata-rata aspek sikap siswa kelas ekspe rimen lebih tinggi dari nilai rata-rata siswa kelas kontrol. Data aspek sikap siswa terdistribusi secara normal dan mempunyai varians yang sama sehingga dapat digunakan uji t. Dari uji $\mathrm{t}$ didapatkan nilai $\mathrm{t}_{\mathrm{h}}=$ 5,7. Nilai $t$ ini berada di luar daerah penerimaan hipotesis Ho. Berarti penggunaan LKS laboratorium virtual dalam pendekatan saintifik mem berikan pengaruh yang berarti pada aspek sikap siswa.

Analisis data aspek sikap siswa dapat pula dianalisis dalam bentuk grafik. Grafik ini berguna untuk melihat hasil penilaian pada aspek sikap dari pertemuan ke pertemuan berikutnya. Pertemuan tatap muka dalam sumbu horizontal dan nilai rata-rata sikap terletak di sumbu vertikal. Grafik dibuat untuk masing-masing penilaian aspek sikap yang dinilai untuk melihat kecendrungan nilai sikap peserta didik setiap pertemuan. 
Indakator-indikator yang dinilai pada setiap aspek sikap telah disatukan menjadi satu penilaian. Indikator yang tercakup pada aspek sikap, yaitu spiritual, disiplin, jujur, kerjasama, percaya diri, dan rasa ingin tahu. Perbedaan aspek sikap pada kedua menunjukkan bahwa Aspek sikap pada kelas eksperi men lebih unggul dari kelas kontrol dikarekanan pemberian perlakuan.

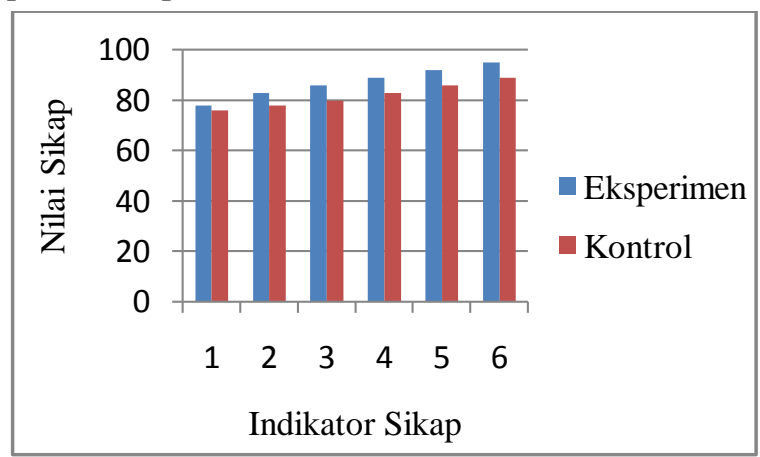

Gambar 1. Hasil Belajar Aspek Sikap Siswa Kedua Kelas Sampel

Gambar 1 merupakan hasil analisis hasil peni laian sikap siswa yang mencakup aspek sikap spiritual, disiplin, jujur, kerjasama, percaya diri, dan rasa ingin tahu. Berdasarkan Gambar 1 data hasil penilaian sikap dianalisis dalam bentuk grafik untuk menjelaskan perbedaan sikap kelas ekperimen dengan kelas kontrol. Bersumber dari hasil analisis yang telah dikemukakan dapat dinyatakan, penerapan LKS laboratorium virtual dalam pendekatan saintifik memberikan perubahan sikap yang baik pada siswa, dikarenakan dengan menggunakan LKS laboratorium virtual dalam pendekatan saintifik siswa dapat mengaksesnya dimana saja tanpa ada batasan waktu.

Kemampuan dan kondisi awal pada aspek sikap siswa tidak berbeda signifikan sebagaimana yang telah dilakukan sebelum menentukan kelas yang akan menjadi kontrol dan eksperimen yang mempunyai rata-rata atau kemamupuan awal yang sama yang dibuktikan dengan nilai $t_{h}$ adalah sebesar 0.243 . Setelah penggunaan LKS laboratorium virtual dalam pendekatan saintifik ternyata terdapat perbeda an yang berarti, adanya perbedaan yang berarti pada aspek sikap mengindikasikan adanya pengaruh peng gunaan LKS laboratorium virtual. Dengan demikian, penggunaan LKS laboratorium virtual member kan pengaruh yang berarti terhadap aspek sikap siswa.

Pengaruh LKS laboratorium virtual pada aspek keterampilan dinilai ketika peserta didik mela kukan kegiatan eksperimen yang sedang berlang sung. Data penilaian diambil sebanyak lima kali kegiatan eksperimen berlangsung. Data penilaian aspek keterampilan siswa didapatkan melalui rubrik penskoran, sehingga didapatkan skor rata-rata, sim pangan (s), dan varians $\left(\mathrm{S}^{2}\right)$ yang digambarkan kedalam bentuk Tabel 8 .
Tabel 8. Penilaian Kelas pada Aspek Keterampilan

\begin{tabular}{lcccc}
\hline \multicolumn{1}{c}{ Kelas } & $\mathrm{N}$ & $\mathrm{Xr}$ & $\mathrm{S}$ & $\mathrm{S}^{2}$ \\
\hline Eksperimen & 32 & 86 & 3,89 & 15,2 \\
Kontrol & 32 & 80 & 4,05 & 16,4 \\
\hline
\end{tabular}

Dari data-data yang terdapat pada Tabel 8 dapat diungkapkan tiga hal. Pertama, nilai rata-rata yang diperoleh pada aspek keterampilan siswa pada kedua kelas sampel menunjukan perbedaan yang signifikan dimana lebih tingginya nilai pada kelas XI MIA 1 dari XI MIA 2. Selanjutnya, nilai untuk kelas MIA 1 lebih merata dibandingkan nilai untuk kelas MIA 2 dikarenakan nilai simpangan kelas MIA 1 lebih kecil dari pada nilai simpangan MIA 2. Ketiga, nilai yang didapat untuk kelas MIA 2 lebih beragam daripada kelas MIA 1 hal ini ditunjukan dari varians kelas MIA 1 lebih rendah dari MIA 2.

Untuk menentukan uji perbandingan yang digunakan pada aspek keterampilan terlebih dahulu dilakukan uji normalitas dan uji homogenitas dari data. Pada uji normalitas didapatkan nilai Lo untuk kelas MIA 1 adalah 0,0782 sedangkan nilai Lo untuk kelas MIA 2 yaitu 0,0894. Data yang didapatkan adalah nilai Lo < Lt, sehingga data dari kedua kelas sampel sama-sama terdistribusi normal. Disisi lain dari uji homogenitas data dari kelas eksperimen dan kelas kontrol diperoleh nilai $\mathrm{F}=1,08$. Ternyata nilai nilai $1,08<1,83$ sehingga dari hasil uji ini dapat dinyakatan kelas sampel memiliki varians homogen.

Data aspek keterampilan siswa pada kelas eksperimen dan kelas kontrol adalah terdistribusi secara normal. Disisi lain, data dari kedua kedua kelas mempunyai varians yang sama. Dengan dasar ini digunakan uji t untuk menentukan perbedaan nilai rata-rata aspek keterampilan dari kelas eksperimen dan kelas kontrol. Hasil uji t untuk data aspek keterampilan ditampilkan pada Tabel 9

Tabel 9. Hasil Uji t dari Aspek Keterampilan

\begin{tabular}{lccccc}
\hline \multicolumn{1}{c}{ Kelas } & $\mathrm{N}$ & $\mathrm{X}$ & $\mathrm{S}^{2}$ & $\mathrm{t}_{\mathrm{h}}$ & $\mathrm{t}_{\mathrm{t}}$ \\
\hline Eksperimen & 32 & 86,0 & 15,31 & & \\
Kontrol & 32 & 80,0 & 16,40 & & 2,0 \\
\hline
\end{tabular}

Dari data pada Tabel 9 dapat dijelaskan bahwa nilai $t_{h}=6,04$. Nilai th ini berada di luar daerah penerimaan hipotesis Ho. Hasil uji ini mengindikasi kan bahwa terdapat perbedaan nilai rata-rata aspek keterampilan antara siswa kelas eksperimen dengan kelas kontrol. Adanya perbedaan yang berarti ini menunjukkan adanya pengaruh dari penerapan lembar kerja siswa laboratorium virtual. Dengan demikian, penggunaan LKS laboratorium virtual fisika dalam pendekatan saintifik memberikan pengaruh yang berarti terhadap aspek keterampilan siswa pada taraf kepercayaan $95 \%$.

Data penilaian aspek keterampilan siswa dijelaskan kedalam bentuk grafik untuk memberikan 
penilaian aspek keterampilan siswa dari pertemuan ke pertemuan selanjutnya selama proses penelitian. Pertemuan tatap muka dalam sumbu vertikal dan nilai rata-rata sikap pada sumbu horizontal. Grafik dibuat untuk semua penilaian aspek sikap spiritual dan sosial yang dinilai untuk melihat bagaimana penilaian aspek sikap peserta didik setiap pertemuan.

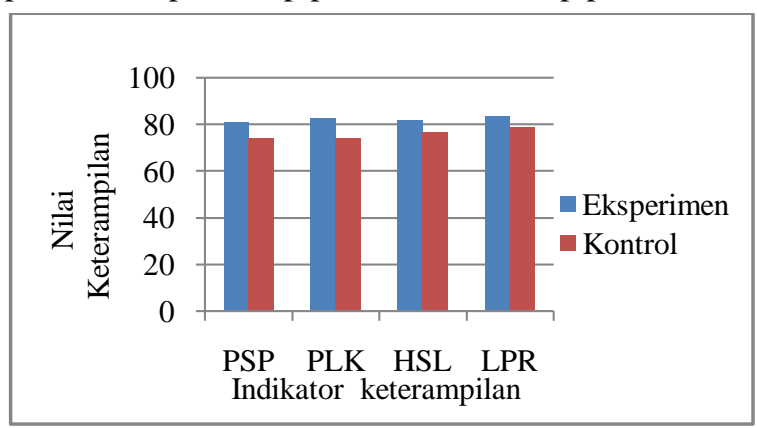

Gambar 2. Hasil Belajar Aspek Keterampilan Kedua Kelas Sampel

Gambar 2 merupakan hasil analisis hasil penilaian keterampilan siswa pada kegiatan eksperi men yang mencakup beberapa kriteria. Berdasarkan Gambar 2 data hasil penilaian keterampilan dianalisis dalam bentuk grafik untuk menjelaskan perbedaan setiap kompentesi aspek keterampilan kelas yang diberikan LKS laboratorium virtual dalam pende katan saintifik dengan kelas yang tidak diberikan LKS laboratorium virtual dalam pendekatan saintifik. Indikator penilaian pada aspek keterampilan yang dinilai yaitu ada empat. Indikator yang pertama yaitu persiapan, kedua pelaksanaan, ketiga hasil, dan keempat laporan. Berdasarkan hasil analisis yang diperoleh dapat dinyatakan, bahwa penerapan LKS laboratorium virtual dalam pendekatan saintifik memberikan perubahan aspek keterampilan yang baik pada siswa, dikarenakan dengan menggunakan LKS laboratorium virtual dalam pendekatan saintifik siswa dapat lebih tertarik mela kukan kegiatan eksperimen dibandingkan dengan melakukan eksperi men di laboratorium.

Kemampuan awal hasil belajar pada aspek keterampilan tidak berbeda signifikan yang telah dilakukan sebelum menentukan kelas sampel yang akan diambil. Setelah penggunaan LKS laboratorium virtual terdapat perbedaan yang signifikan, adanya perbedaan yang berarti pada aspek keterampilan mengindikasikan adanya pengaruh penggunaan LKS laboratorium virtual. Dengan demikian, penggunaan LKS laboratorium virtual memberikan pengaruh yang berarti terhadap hasil belajar pada kompetensi semua aspek.

Berdasarkan data yang telah dijabarkan pada hasil belajar siswa dapat dikemukakan bahwa ada perbedaan hasil belajar yang berarti antara siswa yang menggunakan LKS laboratorium virtual dengan siswa yang menggunakannya. Hal ini berarti penggu naan LKS laboratorium virtual fisika memberikan pengaruh yang berarti terhadap hasil belajar siswa pada aspek pengetahuan, sikap, dan keterampilan. Jadi, penggunaan LKS laboratorium virtual dalam pendekatan saintifik pada materi fluida memberikan dampak yang positif kepada pencapaian nilai fisika siswa dari ketiga aspek yang dinilai.

\section{Pembahasan}

Hasil penelitian pertama yang telah dicapai adalah penggunaan LKS laboratorium virtual dalam pendekatan saintifik memberikan pengaruh yang berarti pada aspek pengetahuan siswa. Nilai siswa pada aspek pengetahuan sebelum diberikan perlakuan hanya dikategorikan cukup namun setelah pengguna an LKS nilai siswa naik menjadi kategori baik. Tercapainya tujuan penelitian ini dikarenakan penerapan LKS laboratorium virtual dalam pendekat an saintifik pada proses pembelajaran.

Berdasarkan data yang telah dianalisis pada penelitian ini menghasilkan nilai rata-rata dari semua penilaian aspek yaitu pengetahuan, sikap dan keteram pilan. Hasil analisis data untuk aspek sikap berupa nilai rata-rata dari enam aspek yang dinilai, kemudian dinyatakan dalam bentuk grafik. Pada penilaian aspek sikap menunjukkan bahwa penerapan LKS laboratorium virtual dalam pendekatan saintifik bias menambah pencapaian indikator pada aspek keterampilan fisika siswa ${ }^{[12]}$. Pernyataan ini dapat dilihat dari grafik rata-rata tiap aspek yang menunjuk kan tingginya nilai rata-rata penilaian dari pertemuan ke pertemuan.

Hasil data yang telah dianalisis untuk penilai an aspek pengetahuan yaitu hasil dari tes akhir, tes tersebut mempunyai komposisi dari materi pembela jaran yaitu fluida. Dari tes akhir penilaian pada aspek pengetahuan menujukkan bahwa nilai rata-rata kelas yang memakai LKS laboratorium virtual jauh lebih baik dibandingkan kelas yang tidak memakai LKS laboratorium virtual yang berselisih rata-ratanya sebesar 6 artinya menunjukkan adanya perbedaan yang berarti. Setelah dilakukan analisis statistik pengujian hipotesis pada penelitian ini didapatkan bahwa terdapat pengaruh penerapan LKS laborato rium virtual dalam pendekatan saintifik terhadap penilaian aspek pengetahuan fisika siswa.

Pada penilaian aspek keterampilan hasil analisis data yang berupa nilai rata-rata kegiatan eksperimen yang dilakukan siswa menunjukkan hasil penilaian aspek keterampilan kedua kelas berbeda adanya perbedaan yang signifikan sedangkan ketika sebelum diberikan LKS laboratorium virtual kedua kelas memiliki kemampuan awal yang sama sehingga berarti terdapat pengaruh penerapan LKS laborato rium virtual dalam pendekatan saintifik terhadap penilaian aspek keterampilan fisika siswa.

Berdasarkan pengamatan selama penelitian, ditinjau dari penilaian aspek sikap. Dari analisis data dapat dinyatakan dalam bentuk grafik menunjukkan siswa yang memakai LKS laboratorium virtual dalam pendekatan saintifik mempunyai sikap yang lebih produktif dibanding dengan siswa yang tidak diberi 
kan LKS laboratorium virtual dalam pendekatan saintifik. Hal ini dapat dilihatdi grafik aspek sikap yang dilakukan penilaian setipa minggunya, pada aspek sikap terlihat jelas bahwa siswa yang menggunakan LKS laboratorium dan siswa yang tidak memiliki grafik yang meningkat. Artinya siswa pada kedua kelas telah memiliki sikap yang lebih baik. Hal ini dikarenakan pengaruh perlakuan berupa LKS laboratorium virtual dalam pendekatan saintifik.

Motivasi siswa dalam belajar tidak terlepas dari penerapan LKS laboratorium virtual dalam pendekatan saintifik. Hal ini sesuai dengan Depdiknas yang menyatakan "salah satu prinsip penyusunan bahan ajar dapat meningkatkan motivasi dan keberhasilan siswa dalam proeses pembelajaran". Pernyataan tersebut dapat dihubungkan dengan hasil penelitian yang didapatkan yaitu penggunaan labora torium virtual dalam pendekatan saintifik bisa menumbuhkan sebuah motivasi untuk melakukan kegiatan eksperimen.

Pada proses pembelajaran siswa yang mema kai laboratorium virtual dalam pendekatan saintifik memiliki pemahaman dan sumber bacaan yang lebih. Eksperimen laboratorium virtual dapat menuntun siswa untuk lebih aktif dalam proses menemukan hal yang baru. Perbedaan juga terlihat pada kedua kelas, terlihat siswa yang menggunakan LKS laboratorium virtual lebih aktif dan lebih memiliki ketertarikan belajar dibanding siswa yang tidak menggunakan LKS laboratorium vitual ${ }^{[13]}$.

Penggunaan laboratorium virtual dalam kegiatan praktikum menjadi sebuah hal baru bagi peserta didik. Hal baru ini membuat mereka mengikuti kegiatan praktikum dengan antusias dan menciptakan rasa ingin tahu dari siswa. Keaktifan siswa dalam kegiatan eksperimen mempengaruhi pemahaman siswa. Pemahaman tersebut dapat diukur guru dan dijadikan acuan untuk menentukan keberhasilan siswa dalam suatu pembelajaran ${ }^{[14]}$.

Penelitian yang dilakukan tak terlepas dari keterbatasan yang hadapi. Kendala yang terjadi di lapangan tak terlepas dari kekurangan-kekurangan yang dimiliki oleh peneliti. Penjelasan tentang kendala yang terjadi selama penelitian diharapkan akan menjadi pengalaman dan dapat diperbaiki untuk masa yang akan datang. Adapun kendala-kendala dan keterbatasan yang dihadapi yaitu materi pelajaran, sumber virtual lab, dan struktur LKS.

Pertama, materi pelajaran yang diterapkan pada penelitian ini masih terbatas. Materi yang diamati tersebut hanya pada fluida statis dan fluida dinamis sehingga terdapat keterbatasan materi pada penelitian yang dilakukan. Kedua, penerapan LKS pada penelitian masih memiliki beberapa kekurangan seperti sumber laboratorium virtual ini berasal dari PhET, dapat dikembangkan dengan menggunakan sumber lain sebagai pengganti sumber $v$-lab. Ketiga, struktur LKS yang digunakan masih menggunakan panduan bahan ajar Depdiknas tahun 2008, LKS ini dapat dikembangkan dengan panduan pengembangan bahan ajar depdiknas tahun 2010.

\section{KESIMPULAN}

Penelitian yang telah dilaksanakan membuah kan hasil penjabaran data dan pembahasan untuk masalah-masalah selama proses penelitian ini maka dapat ditarik sebuah kesimpulan dari penyelidikan ini. Kesimpulannya yaitu penggunaan LKS laborato rium virtual dalam pendekatan saintifik memberikan pengaruh yang signifikan terhadap pencapaian nilai fisika siswa baik pada aspek pengetahuan, sikap, dan keterampilan kelas XI SMAN 14 Padang pada taraf nyata 0,05 .

\section{DAFTAR PUSTAKA}

[1] BNSP. 2006. Standar Isi Untuk Satuan Pendidikan Dasar dan Menengah. Jakarta:

[2] Hamzah B Uno dan Satria Koni. 2012. Assessment Pembelajaran. Jakarta: Bumi Aksara.

[3] Kementrian Pendidikan dan Kebudayaan. 2013. Konsep Pendekatan Scientific. Jakarta: Kemendikbud

[4] Asrizal, A., Yohandri, Y., \& Zulhendri, K. 2018. Studi Hasil Pelatihan Analisis Video dan Tool Pemodelan Tracker pada Guru MGMP Fisika Kabupaten Agam. Jurnal Eksakta Pendidikan, 2 (10), 41-48.

[5] Nashar, H. 2004. Peranan Motivasi \& Kemampuan Awal. Jakarta: Delia Press

[6] Cory, P.S., Asrizal, A., \& Gusnedi, G. (2016). Pembuatan LKS Bermuatan Kecerdasan Kom prehensif untuk Materi Pengukuran, Penjum lahan Vektor dan Gerak Lurus pada Kelas X SMA. Jurnal Eksakta, 1 (XVII), 98-109

[7] E. Mulyasa. 2009. Menjadi Guru Profesional yang Menciptakan Pembelajaran Kreatif dan Menyenangkan. Bandung: Remaja Rosdakarya.

[8] Henlenti, 2014. Pengaruh Media Praktikum Labortorium Virtual untuk Pembelajaran Optikal. Pillar of Physic Education. FMIPA.

[9] Puspita, Rani. 2008. Sistem informasi Aplikasi Virtual Lab Pada Laboratorium Sistem Informasi Universitas Gunadarma.Proceeding, Seminar Ilmiah Nasional Komputer dan Sistem Intelijen (KOMMIT 2008)

[10] Salam, H, 2010. Pengaruh Pembelajaran Berbasis Virtual laboratory Untuk Meningkat kan Penguasaan Konsep. Pillar of Physics Education. FMIPA.

[11] Sudjana. 2005. Metoda Statistika. Bandung: PT. Transito Bandung

[12] Daryanto. 2012. Evaluasi Pendidikan. Jakarta: Rineka Cipta

[13] Slameto. 2001. Evaluasi Pendidikan. Jakarta: Bumi Aksara.

[14] Sani, Ridwan Abdullah. 2014. Pemebelajaran Saintifik untuk Implementasi Kurikulum 2013. Jakarta. PT Bumi Aksara 